\title{
Comparison of Ammonia Emission Estimation between Passive Sampler and Chamber System in Paddy Soil after Fertilizer Application
}

\author{
Min-Suk Kim ${ }^{1}\left(\mathbb{D}\right.$, Namin $\mathrm{Koo}^{2}$, Seunghun Hyun ${ }^{1,3}$ and Jeong-Gyu Kim ${ }^{1,3, *(1)}$ \\ 1 O-Jeong Resilience Institute, Korea University, Seoul 02841, Korea; adoniss86@korea.ac.kr (M.-S.K.); \\ soilhyun@korea.ac.kr (S.H.) \\ 2 Forest Conservation Department, National Institute of Forest Science, Seoul 02455, Korea; koosor@korea.kr \\ 3 Division of Environmental Science and Ecological Engineering, College of Life Science and Biotechnology, \\ Korea University, Seoul 02841, Korea \\ * Correspondence: lemonkim@korea.ac.kr; Tel.:+82-2-3290-3474
}

Received: 13 August 2020; Accepted: 28 August 2020; Published: 2 September 2020

\begin{abstract}
Ammonia $\left(\mathrm{NH}_{3}\right)$ is an important precursor for particulate secondary aerosol formation. This study was conducted to evaluate the applicability of a passive sampler (PAS) for estimating the $\mathrm{NH}_{3}$ emission from chemical fertilizer application $\left(85 \mathrm{~kg}-\mathrm{N} \cdot \mathrm{ha}^{-1}\right)$ at field scale and to compare the results with a chamber system for the calculation of $\mathrm{NH}_{3}$ emission flux at lab scale. The application of chemical fertilizer increased the ambient $\mathrm{NH}_{3}$ concentration from 7.11 to $16.87 \mu \mathrm{g} \cdot \mathrm{m}^{-3}$. Also, the ambient $\mathrm{NH}_{3}$ concentration measured by the PAS was found to be highly influenced by not only the chemical fertilizer application but also the weather (temperature and rainfall). Wind rose diagram data can be useful for understanding the distribution of ambient $\mathrm{NH}_{3}$ concentration. In the case of a chamber with few environmental variables, $\mathrm{NH}_{3}$ was emitted very quickly in the early stages and gradually decreased, whereas it was delayed at intervals of about one week at the site. It was found that daily temperature range, atmospheric disturbance by wind and rainfall, changes in soil moisture, and the presence of a flooded water table were the main influencing factors. The PAS data and the chamber system data were observed to have significant differences in spatial-temporal scale. In order to reduce the gap, it seems to be necessary to further develop a chamber system, in order to improve the precision of field analysis and to strengthen the connection between experimental results.
\end{abstract}

Keywords: ammonia inventory; dry deposition; emission flux; fertilizer spreading; rice transplanting; wind rose diagram

\section{Introduction}

Particulate matter (PM) is a major source of toxicity for human health worldwide and is a bigger problem in Asian countries than in Europe and the United Sstates [1]. In 2013, the International Agency for Research on Cancer (IARC) classified fine $\mathrm{PM}(<2.5 \mu \mathrm{m})$ as a group 1 carcinogen that is recognized as causing cancer in humans and the World Health Organization (WHO) reported that more than 7 million people died earlier than life expectancy due to fine PM in 2014 [2]. In Korea, the average concentration of fine PM was $32.0 \mu \mathrm{g} \cdot \mathrm{m}^{-3}$ in 2015, which was the worst value among 25 Organization for Economic Cooperation and Development (OECD) countries [3]. Although the government has implemented various countermeasures to improve the air quality, there are still frequent cases of high concentrations of PM, so the impact of the efforts to improve the air quality felt by the public has been insufficient [4].

PM can be emitted directly into the air or formed through conversion of gaseous state to particulate state, and the chemical constituents that make up PM (called precursors) are various 
including organic carbon, nitrogen oxides (NOx), sulfur oxides (SOx), ammonia $\left(\mathrm{NH}_{3}\right)$, and trace metals $[5,6]$. Although the exact mechanism of occurrence of urban fine PM is still uncertain, NOx and volatile organic compounds (VOCs) emitted from vehicles seems to be the major causes [7]. On the other hand, in the case of rural areas, the ambient PM is increased by the emission of PM directly from livestock facilities or agricultural machines and by the emission of precursors of particulate matter such as $\mathrm{NH}_{3}$ from livestock manure and nitrogen-based chemical fertilizers [8].

Among several precursors, $\mathrm{NH}_{3}$ is the only basic gas in ambient air that reacts easily with acidic gases such as SOx and NOx to form salts, and thus, emission management and related information are relatively insufficient for other substances [9]. According to the $\mathrm{NH}_{3}$ inventory in Korea, in 2015, more than $77 \%$ of the emitted $\mathrm{NH}_{3}$ originated from the agricultural sector, with emissions resulting from manure management and fertilizer application [10]. However, without considering the seasonal change and cropping system, the emission is simply calculated by multiplying the emission factor $\left(\mathrm{NH}_{3}-\mathrm{kg} \cdot \mathrm{unit}^{-1}\right)$ and activity (unit·year ${ }^{-1}$ ) based on statistical data and established literature [9]. Therefore, in order to accurately quantify the amount of $\mathrm{NH}_{3}$ emission, monitoring of the ambient $\mathrm{NH}_{3}$ concentration and its deposition is necessary.

A passive sampler (PAS) is very suitable tool for long-term measurement in a large area and has the advantages of being easy to handle and cost efficient [11]. In the USA, the National Atmospheric Deposition Program (NADP) and the Ammonia Monitoring Network (AMoN) have continuously monitored $\mathrm{NH}_{3}$ concentrations in the long-term scale, and they reported that the concentration of $\mathrm{NH}_{3}$ and the precipitation of ammonium $\left(\mathrm{NH}_{4}{ }^{+}\right)$shows increasing trends over a large area of the USA [12]. Zbieranowski and Aherne [13] utilized a PAS to evaluate the spatial and temporal variability in ambient $\mathrm{NH}_{3}$ in Canada over three years and reported that agricultural statistical data are well correlated between $\mathrm{NH}_{3}$ concentration and livestock (pig and cattle) heads. Rabaud et al. [14] also used a PAS for the determination of airborne $\mathrm{NH}_{3}$ near a large scale livestock facility. Zhang et al. [15] and Hojito et al. [16] estimated the annual nitrogen $(\mathrm{N})$ deposition in grassland and monitored the vertical distribution of $\mathrm{NH}_{3}$ near an intensive dairy farming area. However, relatively few studies have conducted $\mathrm{NH}_{3}$ monitoring after fertilizer application using PAS [17], and domestic research progress is not significantly different.

Therefore, the purpose of this study was to confirm the applicability of a PAS for monitoring the tendency of $\mathrm{NH}_{3}$ emission during fertilizer treatment in paddy soils in field conditions and to compare the results of $\mathrm{NH}_{3}$ emission calculated through a chamber system in the laboratory.

\section{Materials and Methods}

\subsection{Site Description and Fertilizer Application}

The agricultural paddy soil $\left(1400 \mathrm{~m}^{2}\right)$ is located at Namyangju city, Gyeonggi province, Korea. $\left(37^{\circ} 35^{\prime} 00.8^{\prime \prime} \mathrm{N}, 127^{\circ} 14^{\prime} 17.8^{\prime \prime} \mathrm{E}\right)$ and has been farming rice for several years (Figure 1). The $\mathrm{pH}$, clay content, bulk density and soil organic carbon of the field paddy soil were $6.2,22 \%, 1.2 \mathrm{~g} \cdot \mathrm{cm}^{-3}$ and $3.0 \%$, respectively [18] with the soil analysis was conducted according to the guidelines of National Institute of Agricultural Science and Technology (NIAST) [19]. The paddy soil was left unattended during the winter season and tillage was conducted on 23 April 2020. After two weeks (7 May 2020), commercial composite fertilizer ( $25 \%$ nitrogen content) was applied with the input ration of $85 \mathrm{~kg}-\mathrm{N} \cdot \mathrm{ha}^{-1}$ and then, the paddy soil was mixed and irrigated. After two weeks of aging (21 May 2020), the seedlings of rice were transplanted during submerged conditions. Before the fertilizer application, soil samples were collected for the chamber experiment in the laboratory. The collected soil samples were air-dried, passed through a $4 \mathrm{~mm}$ sieve, and stored in a polyethylene bottle until used in the chamber experiment. 


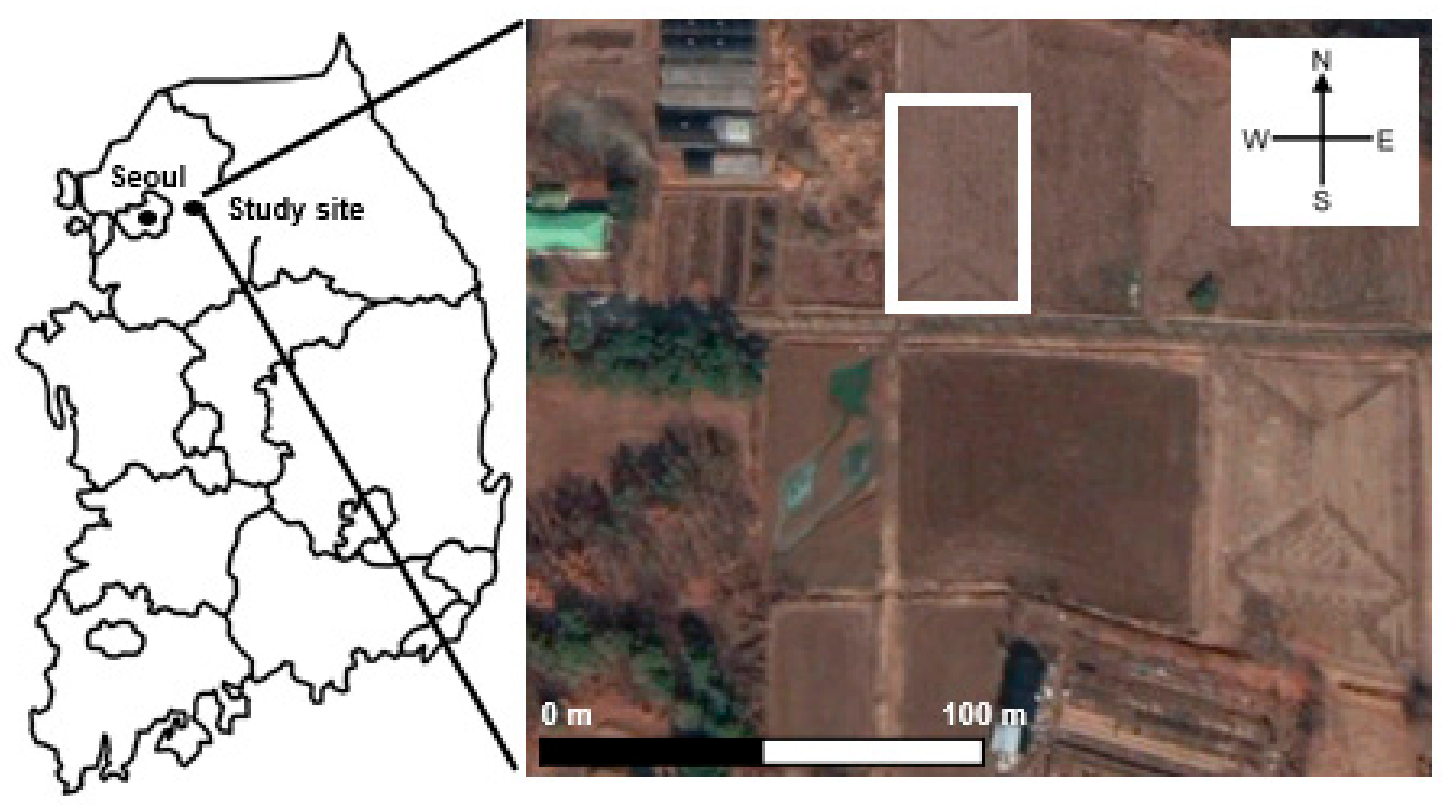

Figure 1. Satellite view (Google Earth Pro, 2020) of the study site (outlined in white) and neighboring fields.

\subsection{On-Site Passive Samper Experiement}

The commercial Radiello ${ }^{\circledR}$ passive samplers (PAS) (Radiello, Pavia, Italy) was selected for the field monitoring of $\mathrm{NH}_{3}$ concentrations. Each sampler included a blue diffusive body (RAD1201), cartridge adsorbents (RAD168), and vertical adapter (RAD122), which were purchased through Sigma Aldrich. Each sampler was put in a rain shelter made of stainless steel that was placed approximately $2 \mathrm{~m}$ above ground. A total of 17 shelters were installed in a zigzag formation to cover all of the experimental area. After one week of exposure, each diffusive body and cartridge was replaced with a new one every week, and the experiment was performed during six weeks from 23 April 2020 to 4 June 2020. By placing two repetitions in one shelter, a total of 204 cartridge samples were collected. Cartridges collected one week after exposure were immediately sealed and brought to the laboratory. The $\mathrm{NH}_{3}$ adsorbed on the cartridge was extracted with $10 \mathrm{~mL}$ of deionized water and a vortex, and the $\mathrm{NH}_{4}{ }^{+}$concentration in the extractant was quantified by indophenol blue colorimetric method using a UV-VIS spectrophotometer (Optizen POP, Mecasys Co. Ltd., Daejeon, Korea). A blank value did not exceed 0.040 absorbance units. The limit of detection (LOD), limit of quantification (LOQ) were 0.036 and $0.119 \mathrm{NH}_{4}-\mathrm{N} \mathrm{mg} \cdot \mathrm{L}^{-1}$, respectively. The ambient $\mathrm{NH}_{3}\left(\mathrm{C}_{\mathrm{N}}, \mu \mathrm{g} \cdot \mathrm{m}^{-3}\right)$ concentration was calculated as follows:

$$
\mathrm{C}_{\mathrm{N}}=0.944 \times m \times 1,000,000 / 235 / t
$$

where $m$ is the mass of $\mathrm{NH}_{4}{ }^{+}(\mu \mathrm{g})$ in the cartridge, $t$ is the exposure time (minutes) and 0.944 is the factor to convert $\mathrm{NH}_{4}{ }^{+}$to $\mathrm{NH}_{3}$. The value of 235 refers to the sampling rate $\left(\mathrm{Q}_{298}, \mathrm{~mL} \cdot \mathrm{min}^{-1}\right)$ at $298 \mathrm{~K}$ and $1013 \mathrm{hPa}$. For quality assurance and quality control, parallel duplicate samples, field blanks and travel blanks were performed [20]. The LOD and uncertainty values were $1 \mu \mathrm{g} \cdot \mathrm{m}^{-3}$ for $24 \mathrm{~h}$ exposure and $6.5 \%$ at $2 \sigma$, respectively. In order to confirm the effect of the weather, data (temperature, rainfall and wind) were collected from nearby a national automatic weather system (AWS) in Korea.

\subsection{Chamber Experiement in Laboratory}

Since a PAS collects $\mathrm{NH}_{3}$ that is deposited, a dynamic chamber-capture system (DCS) was used to quantify the amount of $\mathrm{NH}_{3}$ emitted from fertilizer after soil application [21]. Briefly, after application of fertilizer to the soil at the same ratio as the treated site $\left(85 \mathrm{~kg}-\mathrm{N} \cdot \mathrm{ha}^{-1}\right)$, the chamber was sealed, and all air was passed through a boric acid solution $(5 \%)$ in the bubbler to capture the entire amount of 
$\mathrm{NH}_{3}$ using a vacuum pump (15 L per min). Captured $\mathrm{NH}_{3}$ was immediately quantified by indophenol blue colorimetric method.

First, $10 \mathrm{~cm}$ of soil was placed in the chamber and sealed without fertilizer application. At this time, the moisture content of soil was standardized by using measurement of the moisture content of the field soil at the date of installation of the PAS cartridge (23 April 2020). In order to ensure constant moisture content of the soil, moisture was supplied according to the weight every day. The $\mathrm{NH}_{3}$ emitted from the soil was continuously captured for two weeks using a boric acid bubbler, and the temperature was adjusted daily according to the observed average daily temperature by AWS. After two weeks, the chamber was opened, fertilizer was added, and irrigation was performed until the soil was saturated, to the same conditions as recorded in the field (7 May 2020). After closing the chamber, the $\mathrm{NH}_{3}$ was captured and quantified in the same manner as in the method during the previous four weeks. However, the chamber was unable to simulate the transplanting treatment in the field, so $\mathrm{NH}_{3}$ emission was continuously measured for four weeks after the fertilizer treatment. In addition, in order to compare the effect of irrigation on $\mathrm{NH}_{3}$ volatilization, an additional treatment that did not include irrigation after the fertilizer application was also performed.

The bubbler containing the boric acid solution was replaced with a new one every $24 \mathrm{~h}$ after the start of the experiment, and the $\mathrm{NH}_{3}$ emitted from the soil was quantified once a day. After the quantification of captured $\mathrm{NH}_{3}$, the $\mathrm{NH}_{3}$ emission flux $\left(\mathrm{mg} \cdot \mathrm{m}^{-2} \cdot \mathrm{h}^{-1}\right)$ was calculated considering the surface area of the chamber $\left(\mathrm{m}^{-2}\right)$. The process and results of quality assurance and quality control were confirmed through a previous study [21] and all of the chamber experiments were performed in three replicates.

\section{Results and Discussion}

\subsection{Site Weather Information during the Experiment}

The average, minimum, and maximum temperatures during the six-week field study period were $17.21{ }^{\circ} \mathrm{C}, 11.47^{\circ} \mathrm{C}$, and $23.62{ }^{\circ} \mathrm{C}$, respectively. The average, minimum, and maximum temperatures for the two weeks after tillage were $15.75^{\circ} \mathrm{C}, 8.77^{\circ} \mathrm{C}$, and $22.74{ }^{\circ} \mathrm{C}$, respectively (Figure 2a). The average, minimum, and maximum temperatures for the two weeks after chemical fertilizer application and irrigation were $16.77^{\circ} \mathrm{C}, 11.81^{\circ} \mathrm{C}$, and $22.55^{\circ} \mathrm{C}$, respectively (Figure 2b). The average, minimum, and maximum temperatures for the two weeks after transplanting the rice seedlings were $19.28^{\circ} \mathrm{C}$, $13.72{ }^{\circ} \mathrm{C}$, and $25.77^{\circ} \mathrm{C}$, respectively (Figure 2c). During the first two weeks after tillage, there was no effective rainfall (Figure 2a). In the two weeks after the chemical fertilizer application and irrigation, a total of $80.5 \mathrm{~mm}$ of rain fell (Figure 2b). After transplanting the rice seedlings, it rained $20.0 \mathrm{~mm}$ until the end of the experiment (Figure 2c). The season in the study site was spring, and as the experiment progressed, the temperature showed an increasing trend. During rainy conditions, the average temperature was relatively low. In the second period (Figure 2b), it rained the most, and the average temperature was relatively low.

The average wind speed during the six-week field study period was $1.68 \mathrm{~m} \cdot \mathrm{s}^{-1}$. The average wind speed according to the three aforementioned periods discussed for temperature, was $1.90 \mathrm{~m} \cdot \mathrm{s}^{-1}$, $1.69 \mathrm{~m} \cdot \mathrm{s}^{-1}$, and $1.44 \mathrm{~m} \cdot \mathrm{s}^{-1}$, respectively (Figure 3). The proportion of calms wind (under $0.5 \mathrm{~m} \cdot \mathrm{s}^{-1}$ ) during each period was $9.78 \%, 9.32 \%$, and $11.30 \%$, respectively. After transplanting the rice seedlings, the average wind speed was the lowest and the most silent period (Figure 3). The main wind direction of the six-week period, not including periods with calm wind (10.4\%) was (in the order of highest to lowest) west-south-west $(14.1 \%)$, west $(10.7 \%)$, and north-north-east $(9.4 \%)$. This trend of wind direction was similar after tillage (Figure 3a) and after transplanting the rice seedlings (Figure 3c). During the two weeks of heavy rain (Figure $3 b$ ), various wind directions were observed due to atmospheric disturbance and instability. 

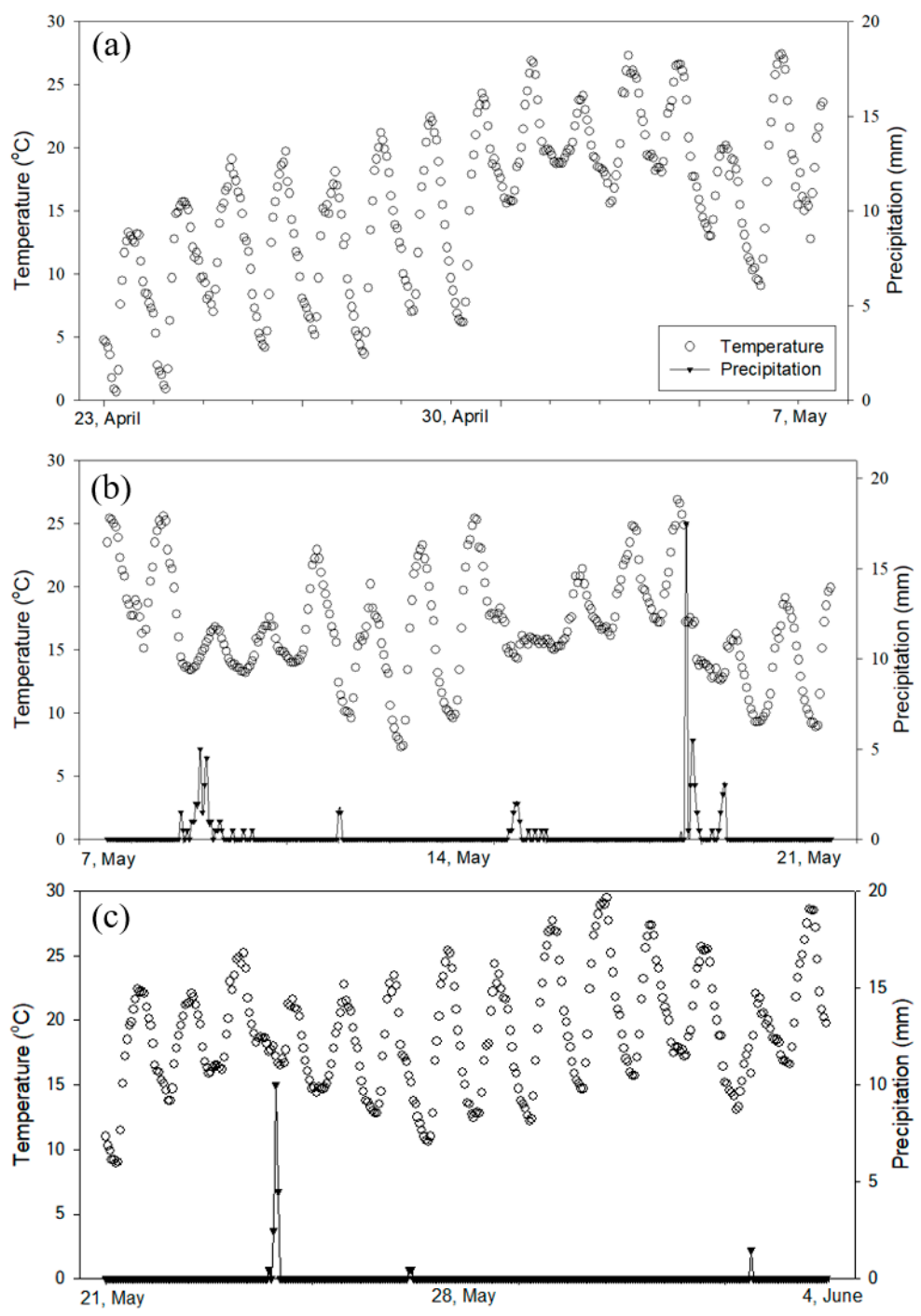

Figure 2. Temperature (left y-axis) and precipitation (right y axis) in the study site during April 23-June 4. (a) After tillage (April 23-May 7); (b) After chemical fertilizer application and irrigation (May 7-May 21);

(c) After transplanting rice seedlings (May 21-June 4).

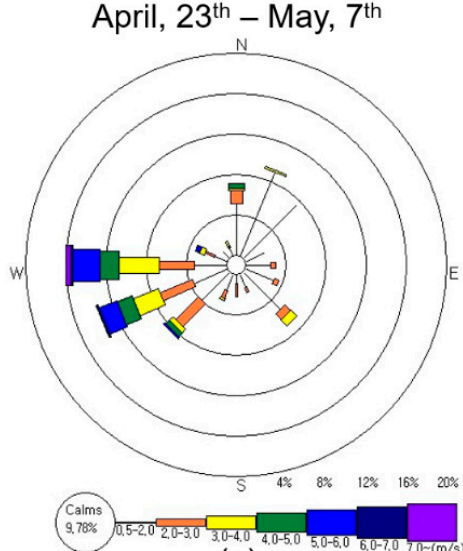

(a)

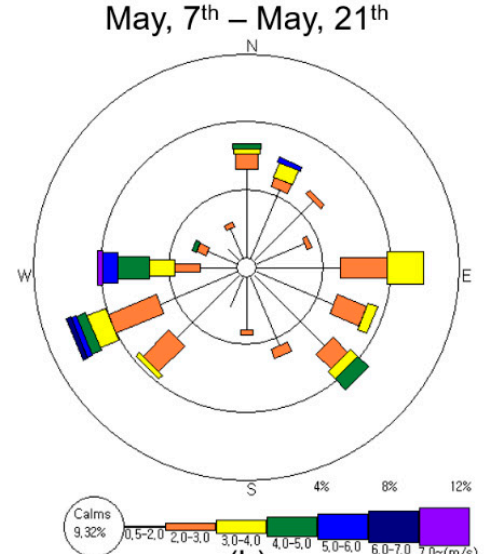

(b)

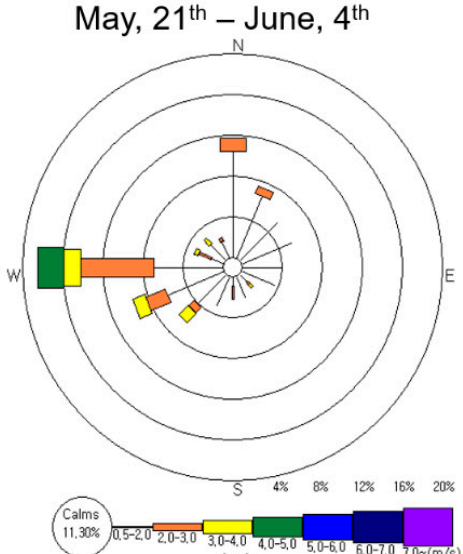

(c)

Figure 3. Wind rose diagrams of the study site during April 23-June 4. Calm wind refers to when the wind speed is lower than $0.5 \mathrm{~m} \cdot \mathrm{s}^{-1}$. (a) After tillage (April 23-May 7); (b) After chemical fertilizer application and irrigation (May 7-May 21); (c) After transplanting rice seedlings (May 21-June 4). 


\subsection{Ambient $\mathrm{NH}_{3}$ Concentration in the Study Site}

The average concentration, standard deviation, and minimum-maximum range of ambient $\mathrm{NH}_{3}$ during the six-week study period was $11.29 \mu \mathrm{g} \cdot \mathrm{m}^{-3}, 5.02 \mu \mathrm{g} \cdot \mathrm{m}^{-3}$, and $5.47-19.96 \mu \mathrm{g} \cdot \mathrm{m}^{-3}$, respectively. Divided into two-week periods according to the order of the experiment, the concentration of ambient $\mathrm{NH}_{3}$ gradually increased to $7.11,7.25$ and $16.87 \mu \mathrm{g} \cdot \mathrm{m}^{-3}$, respectively (Figure 4). High concentrations of $\mathrm{NH}_{3}$ were distributed around the center of the target study site during all experiments. The southern part of study site is adjacent to the road, resulting in generally low concentrations of $\mathrm{NH}_{3}$ due to the distance from the nearby farmland. It has been previously shown that the main sources of atmospheric $\mathrm{NH}_{3}$ were animal manure and $\mathrm{N}$-based fertilizers [22]. Dry deposition of $\mathrm{NH}_{3}$ is a one of the major removal mechanisms from ambient air to soil surfaces, and a PAS can adsorb and capture falling $\mathrm{NH}_{3}$ by diffusion $[22,23]$. Since the area around the study site is also agricultural land, $\mathrm{NH}_{3}$ from the surrounding area may have been captured in the PASs of our study site. However, as $\mathrm{NH}_{3}$ concentration is high in the central part where the PASs were installed and decreased toward the boundary of the periphery, it has been supposed that the $\mathrm{NH}_{3}$ emitted from our research site was mainly collected and that the results of spatial distribution were observed. During the two-week capture period (April 23-May 7), there was no compost and fertilizer use in the study soil or any surrounding soils, and the deposition and capture distribution of $\mathrm{NH}_{3}$ was concentrated in the center of study site, as shown in Figure 4a. Despite the fact that fertilizer was not applied, a significant amount of $\mathrm{NH}_{3}$ was emitted (in the $5.47-8.43 \mu \mathrm{g} \cdot \mathrm{m}^{-3}$ range), and the reason for this could be found in the tillage practice. During the cold winter, the soil that was not cultivated and that was left unattended begins the next farming cycle with tillage in the spring season. Tillage loosen the top layer of soil, enhances organic nitrogen mineralization, and reduces the resistance to $\mathrm{NH}_{3}$ diffusion by top soil, resulting in the production of ammonium $\left(\mathrm{NH}_{4}{ }^{+}\right)$and the emission of $\mathrm{NH}_{3}$ [24].

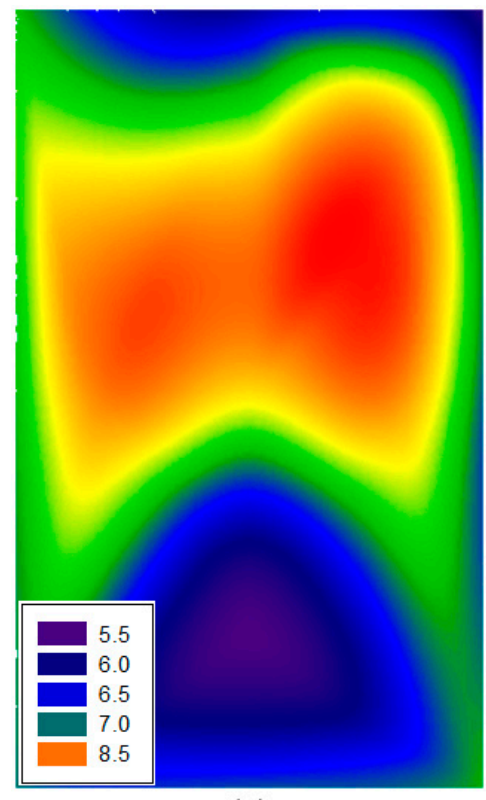

(a)

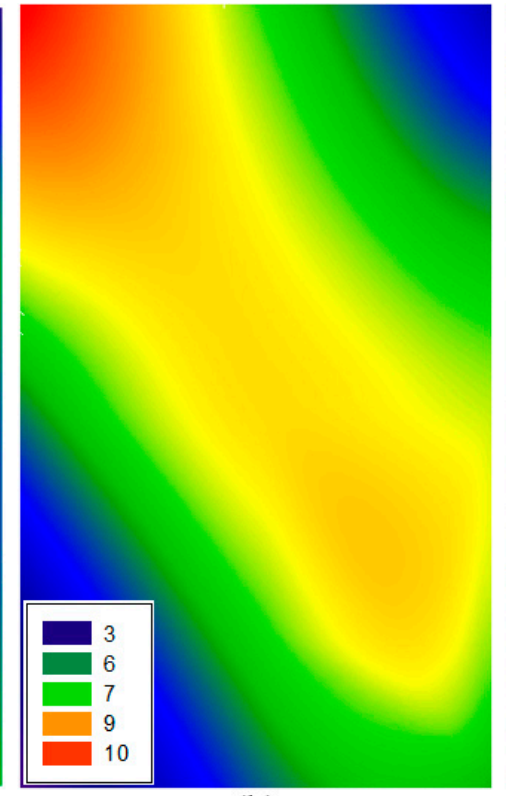

(b)

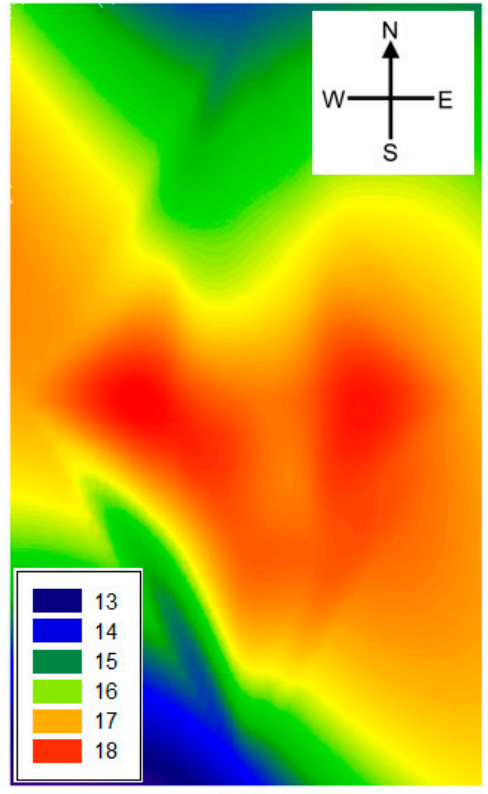

(c)

Figure 4. Changes in the spatial distribution of ammonia $\left(\mathrm{NH}_{3}\right)$ concentration $\left(\mu \mathrm{g} \cdot \mathrm{m}^{-3}\right)$ in the study site. (a) After tillage (April 23-May 7); (b) After chemical fertilizer application and irrigation (May 7-May 21);

(c) After transplanting rice seedlings (May 21-June 4).

After the chemical fertilizer application, the average concentration of ambient $\mathrm{NH}_{3}$ during the two weeks was $7.25 \mu \mathrm{g} \cdot \mathrm{m}^{-3}$ (Figure $4 \mathrm{~b}$ ). Hayashi et al. [25] reported that $\mathrm{NH}_{3}$ volatilization began on the day after fertilizer application $\left(63.6 \mathrm{~kg} \mathrm{~N} \cdot \mathrm{ha}^{-1}\right)$ in an upland field where there was nothing that interfered with the volatilization of $\mathrm{NH}_{3}$. On the contrary, the transformation and behavior of 
nitrogen from fertilizer is unique in paddy soil due to the effect of the layer of the free water table. A flooded water table interferes with the supply of oxygen to the soil, resulting in the creation of redox conditions and enhancing runoff, seepage, and the leaching of nitrogen [26]. Also, rainfall can reduce $\mathrm{NH}_{3}$ volatilization in soil and enhance wet deposition in the atmosphere, causing a decrease in ambient $\mathrm{NH}_{3}$ concentrations $[27,28]$. In this study, irrigation was carried out immediately after the fertilizer application, and after that, a total of $80.5 \mathrm{~mm}$ of rain fell on four rainfall events in two weeks. For this reason, despite the application of nitrogen chemical fertilizer, $\mathrm{NH}_{3}$ emission and deposition did not increase when compared to after tillage (Figure 4a).

A significant increase in ambient $\mathrm{NH}_{3}$ concentrations was observed after transplanting the rice seedlings (Figure 4c). It is known that $\mathrm{NH}_{3}$ volatilization is increased in paddy soils as the $\mathrm{NH}_{4}{ }^{+}$ concentration in floodwater increases and the flooded water table decreases [29]. Also, an increase in temperature is an intuitive factor for increasing ambient $\mathrm{NH}_{3}$ concentrations. The increases in soil temperature promote soil microbial activity and increase the $\mathrm{NH}_{3} / \mathrm{NH}_{4}{ }^{+}$ratio in the liquid phase of the flooded water table, resulting in enhancement of $\mathrm{NH}_{3}$ volatilization [30,31]. During the transplanting on May 21, the paddy soil and water table were disturbed, and there was only one rainfall event $(20.0 \mathrm{~mm})$ after planting. Therefore, as time went by, the amount of $\mathrm{NH}_{4}{ }^{+}$in the flooded water was increased and at the same time the flooded water table was decreased due to evaporation, resulting in the increases in ambient $\mathrm{NH}_{3}$ concentrations. Rice has been known to act as an absorber for $\mathrm{NH}_{3}$ in the atmosphere and at the same time serves as an emitter [32]. However, in this study, it is considered that this effect was negligible because rice seedlings are small in size only two weeks after transplantation.

The effect of rainfall on ambient $\mathrm{NH}_{3}$ distribution could be confirmed by comparing Figures 3 and 4. In Figure 3a,c, the wind direction is consistently common, which shows a high concentration of ambient $\mathrm{NH}_{3}$ in the center of the target study site (Figure $4 \mathrm{a}, \mathrm{c}$ ). In addition, the frequency of high wind speeds was not high, and the situation with little or no rainfall seems to have contributed to this result. Between May 7 and May 21, when the rain was relatively frequent, the direction and frequency of the wind was very diverse, resulting in a different trend of distribution of ambient $\mathrm{NH}_{3}$ concentrations compared to Figure 4a,c.

\subsection{Long-Term Monitoring of $\mathrm{NH}_{3}$ Emission using the Chamber System}

The amount of volatilized $\mathrm{NH}_{3}$ was captured and determined for six weeks (Figure 5) using a chamber system with a recovery rate of $98.2 \%$ [21]. The total amount of $\mathrm{NH}_{3}$ emitted from soil during the two weeks after tillage was $52.02 \mathrm{mg} \cdot \mathrm{m}^{-2}$. After fertilizer application, the $\mathrm{NH}_{3}$ emission increased dramatically, and the accumulated emission was higher when irrigation was not performed. The total amount of $\mathrm{NH}_{3}$ emitted from soil during the six weeks was $2839.04 \mathrm{mg} \cdot \mathrm{m}^{-2}$ and $3466.69 \mathrm{mg} \cdot \mathrm{m}^{-2}$, respectively, with and without irrigation practice (Figure 5a). The cumulative emissions continued to increase after fertilizer application, while the $\mathrm{NH}_{3}$ emission flux per unit hour was highest in the first week immediately after fertilizer application (Figure $5 b$ ). In the early stage immediately after fertilizer application, the emission flux was faster when irrigation was performed, but the maximum emission flux was higher when irrigation was not performed $\left(0.88 \mathrm{mg} \cdot \mathrm{g}^{-2} \cdot \mathrm{h}^{-1}\right)$. From the second week after fertilizer application, the emission flux gradually decreased, but it was still higher than before the fertilizer application. Additionally, the emission flux was always higher when the irrigation was not performed than when irrigation was performed throughout the entirely of the chamber experiment.

In general, there are three types of nitrogen fertilizers that can be applied to agricultural soil: solid compost from manure, sludge, or food waste; solid chemical fertilizer; and liquid fertilizer from manure [33]. In order for $\mathrm{NH}_{3}$ to be volatilized into the atmosphere from the solid types of fertilizer, nitrogen in the fertilizer should be primarily dissolved into the solution in the form of $\mathrm{NH}_{3}$ or $\mathrm{NH}_{4}{ }^{+}$[26]. Most nitrogen in chemical fertilizers is in the form of $\mathrm{NH}_{4}{ }^{+}$or $\mathrm{NO}_{3}{ }^{-}$, so it is easy to volatilize after dissolution. However, nitrogen in organic waste resources is often present in the form of organic matter, which takes more time to mineralize until volatilization with $\mathrm{NH}_{3}$. Gao et al. [34] observed that the mineralization of nitrogen and the resulting increase in $\mathrm{NH}_{3}$ volatilization appeared after 6 days 
of incubation. DeLaune et al. [35] also reported that it took 10 to 14 days for the solid chemical to dissolve, resulting in lower $\mathrm{NH}_{3}$ emissions from poultry litter. In the case of liquid fertilizer and liquid manure or slurry, a large amount of nitrogen is present in the form of total ammoniacal nitrogen (TAN, $\mathrm{NH}_{3}+\mathrm{NH}_{4}{ }^{+}$), so it is relatively easy to emit to the atmosphere [36]. Kim et al. [21], who considered the $\mathrm{NH}_{3}$ emission from livestock liquid fertilizer (the ratio of TAN to TN is $86 \%$ ), determined that the emission flux $\left(\mathrm{mg} \cdot \mathrm{m}^{-2} \cdot \mathrm{h}^{-1}\right)$ was the highest immediately after spreading, and rapidly decreased for $24 \mathrm{~h}$, after which it showed a very low value.

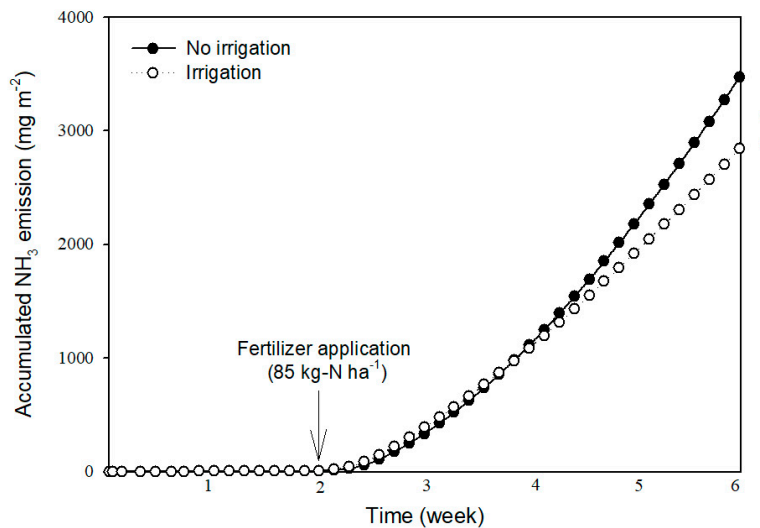

(a)

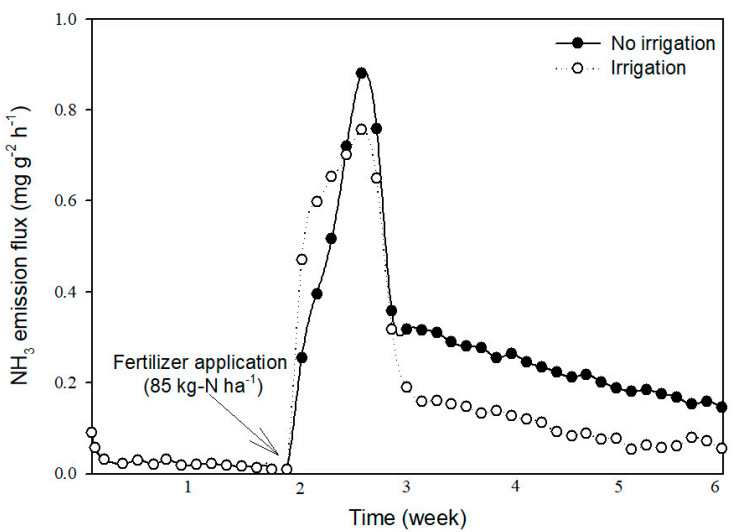

(b)

Figure 5. Changes in accumulated $\mathrm{NH}_{3}$ emission (a) and $\mathrm{NH}_{3}$ emission flux (b) when chemical fertilizer was applied to soil during a six-week period.

To examine to what extent a PAS could reflect $\mathrm{NH}_{3}$ emission from soil, the relationship between on-site PAS results (y-axis) and lab-chamber results (x-axis) was confirmed excluding the results of the third and fourth weeks, which had been disturbed by rainfall (Figure 6). The PAS result corresponding to the y-axis was relatively small due to the variation in the concentration of $\mathrm{NH}_{3}$ in the cartridges captured from 17 shelters for a week, but the emission flux corresponding to the $\mathrm{x}$-axis was determined in units of one day, resulting in a large deviation. Also, the deviation was very large in the first and third weeks because the emission flux was high after tillage (first week) and after the fertilizer application (third week), and decreased rapidly with time. At the second and sixth weeks, the emission flux from the chamber decreased compared to the first and fifth weeks, but the ambient $\mathrm{NH}_{3}$ concentration was higher at the field site. There might be several reasons for this trend. First, the set temperature in the chamber utilized the average daily temperature observed in the field, so the maximum daily temperature was not sufficiently reflected in the chamber. For example, average temperatures were $8.1{ }^{\circ} \mathrm{C}$ and $16.5^{\circ} \mathrm{C}$ but the highest temperatures were $13.3^{\circ} \mathrm{C}$ and $22.4^{\circ} \mathrm{C}$ on April 23 and May 21, respectively. It has been shown that increases in surface temperature from high radiation levels from daylight have the effect of increasing atmospheric instability, resulting in the enhancement of $\mathrm{NH}_{3}$ volatilization [37]. Therefore, in the second and sixth weeks, when there were many days when the highest temperature was high, more $\mathrm{NH}_{3}$ was emitted from the soil, and it seems that the ambient concentration in the atmosphere increased. Another reason would be the effect of soil moisture. During the first and second weeks, while water was added and adjusted daily to maintain the initial soil moisture during the chamber experiment, rainfall was the only source of moisture in the field experiment. Increased soil moisture promotes soil microbial activity and TAN concentrations, thereby enhancing $\mathrm{NH}_{3}$ emission [38]. During the fifth and sixth weeks, a reduction of the flooded water table by evaporation caused high TAN concentrations in solution and thus high $\mathrm{NH}_{3}$ emission losses [39]. In addition, the $20.0 \mathrm{~mm}$ rainfall during fifth week also seems to have contributed to diluting the TAN in the flooded water table (Figure 2c) [40]. In addition to these factors, changes in wind speed, influences from nearby farmland, and the delay effect mentioned in the previous section may also have had impacts. 


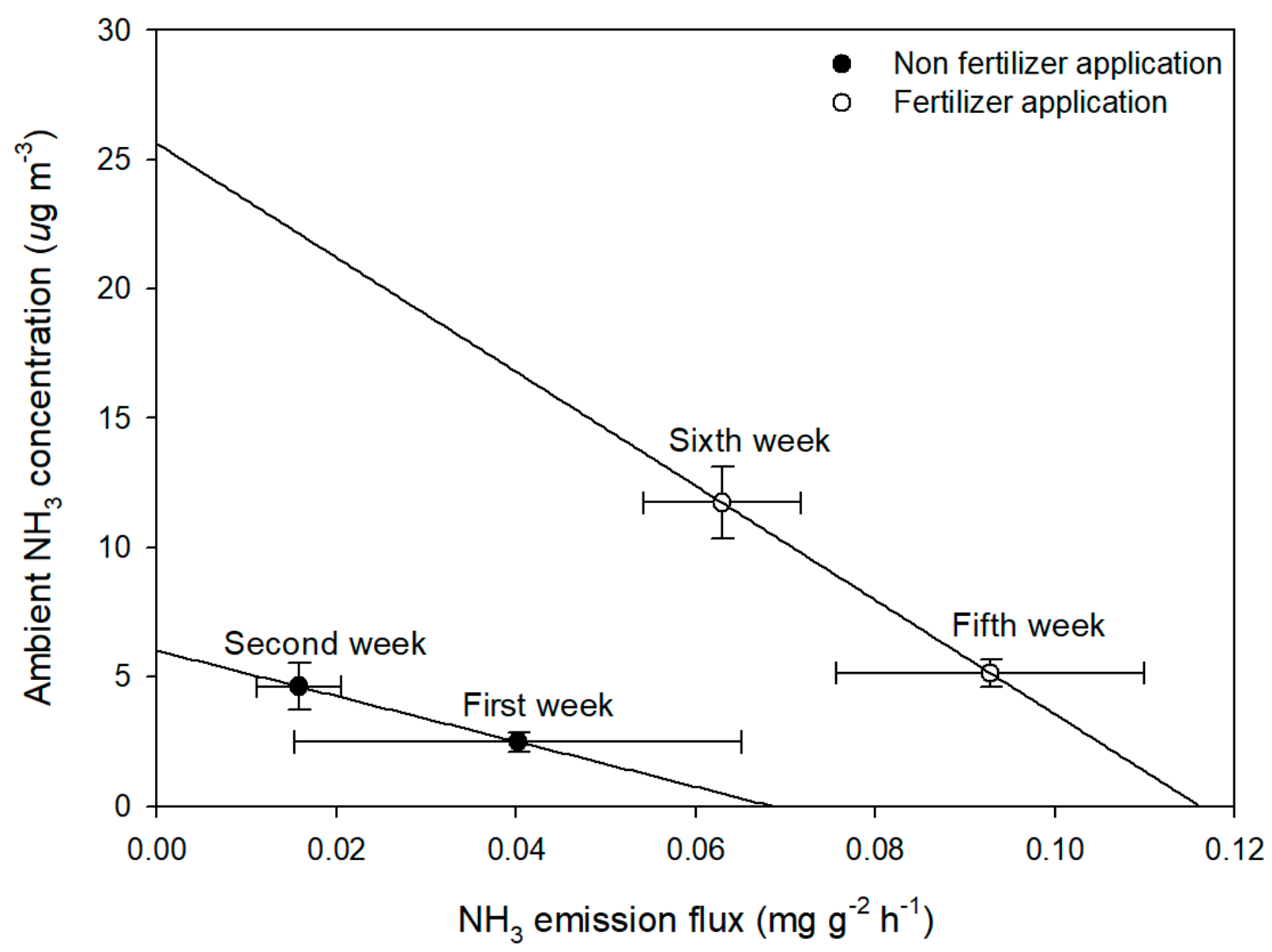

Figure 6. Relationship between $\mathrm{NH}_{3}$ emission flux by chamber experiment at lab scale and ambient $\mathrm{NH}_{3}$ concentration by passive sampler experiment at field scale.

\section{Conclusions}

In this study, the applicability of a PAS to monitoring the tendency of $\mathrm{NH}_{3}$ emissions during fertilizer treatment in paddy field soil was evaluated and compared with the results of $\mathrm{NH}_{3}$ emission calculated through a chamber system in the laboratory. It was confirmed that a PAS could be utilized to demonstrate the distribution of ambient $\mathrm{NH}_{3}$ concentrations in agricultural land. Chamber systems also seem to be utilizable for estimating $\mathrm{NH}_{3}$ emission fluxes and trends. However, it seems that the $\mathrm{NH}_{3}$ volatilization into the atmosphere after fertilizer application was delayed by flooded water table conditions and rainfall of considerable intensity. Additionally, it was determined that wind rose diagram information is useful for interpreting the ambient $\mathrm{NH}_{3}$ concentration results. A chamber system that is capable of capturing and analyzing the entire amount of $\mathrm{NH}_{3}$ emitted from the soil should be developed in order to allow for accurate determination of $\mathrm{NH}_{3}$ emission. In order to allow for a more accurate understanding of experiment results produced in both field and laboratory settings, chamber systems and PASs should be used in tandem more often. Additionally, their combined usage could be especially important for strengthening the connection with weather data.

Author Contributions: Conceptualization, M.-S.K.; methodology, N.K.; writing-original draft preparation, M.-S.K.; writing-review and editing, J.-G.K., S.H. All authors have read and agreed to the published version of the manuscript.

Funding: This research was funded by the National Research Foundation of Korea (NRF) (2019R1I1A1A01043684) and partly supported by Korea University.

Conflicts of Interest: The authors declare no conflict of interest. The funders had no role in the design of the study; in the collection, analyses, or interpretation of data; in the writing of the manuscript, or in the decision to publish the results. 


\section{References}

1. Mukherjee, A.; Agrawal, M. World air particulate matter: Sources, distribution and health effects. Environ. Chem. Lett. 2017, 15, 283-309. [CrossRef]

2. World Health Organization. 7 Million Premature Deaths Annually Linked to Air Pollution. 2014. Available online: http://www.who.int/mediacentre/news/releases/2014/air-pollution/en (accessed on 31 May 2020).

3. Organization for Economic Cooperation and Development. Exposure to PM2.5 in Countries and Regions. 2014. Available online: http://stats.oecd.org/index.aspx?queryid=72722 (accessed on 31 May 2020).

4. Shin, D.W.; Joo, H.S.; Seo, E.; Kim, C.Y. Management Strategies to Reduce PM-2.5 Emission: Emphasis-Ammonia; Korea Environment Institute: Sejong City, Korea, 2017.

5. Zhang, R.; Khalizov, A.; Wang, L.; Hu, M.; Xu, W. Nucleation and growth of nanoparticles in the atmosphere. Chem. Rev. 2012, 112, 1957-2011. [CrossRef] [PubMed]

6. Zhang, R.; Wang, G.; Guo, S.; Zamora, M.L.; Ying, Q.; Lin, Y.; Wang, W.; Hu, M.; Wang, Y. Formation of urban fine particulate matter. Chem. Rev. 2015, 115, 3803-3855. [CrossRef]

7. Huan, L.; Kebin, H. Traffic optimization: A new way for air pollution control in China's urban areas. Environ. Sci. Technol. 2012, 46, 5660-5661. [CrossRef] [PubMed]

8. Winkel, A.; Ogink, N.W.M.; Aarnink, A.J.A.; Koerkamp, P.W.G. Livestock farms ad major emissions source of atmospheric particles in the Netherlands: Lessons learned and future perspectives. In Proceedings of the International Symposium on Animal Environment and Welfare, Chongqing, China, 23-25 October 2017; pp. 23-31.

9. Kim, M.S.; Koo, N.; Kim, J.G. A comparative study on ammonia emission inventory in livestock manure compost application through a foreign case study. Korean J. Environ. Biol. 2020, 38, 71-81. [CrossRef]

10. National Institute of Environmental Research. 2016 National Air Pollutants Emissions; National Institute of Environmental Research: Incheon, Korea, 2019.

11. Thöni, L.; Seitler, E.; Blatter, A.; Neftel, A. A passive sampling method to determine ammonia in ambient air. J. Environ. Monit. 2003, 5, 96-99. [CrossRef]

12. Butler, T.; Vermeylen, F.; Lehmann, C.M.; Likens, G.E.; Puchalski, M. Increasing ammonia concentration trends in large regions of the USA derived from the NADP/AMoN network. Atmos. Environ. 2016, 146, 132-140. [CrossRef]

13. Zbieranowski, A.L.; Aherne, J. Spatial and temporal concentration of ambient atmosphere ammonia in southern Ontario, Canada. Atmos. Environ. 2012, 62, 441-450. [CrossRef]

14. Rabaud, N.E.; James, T.A.; Ashbaugh, L.L.; Flocchini, R.G. A passive sampler for the determination of airborne ammonia concentrations near large-scale animal facilities. Environ. Sci. Technol. 2001, 35, 1190-1196. [CrossRef]

15. Zhang, Y.; Xu, W.; Wen, Z.; Wang, D.; Hao, T.; Tang, A.; Liu, X. Atmospheric deposition of inorganic nitrogen in a semi-arid grassland of inner Mongnolia, China. J. Arid Land 2017, 9, 810-822. [CrossRef]

16. Hojito, M.; Hayashi, K.; Matsuura, S.; Kohyama, K. Two-year monitoring of the vertical distrivution of ammonia in the atmosphere above an intensive dairy farming area in central Japan. J. Jpn. Soc. Atmos. Environ. 2010, 45, 166-170.

17. Hayashi, K.; Koga, N.; Yanai, Y. Effects of field applied composted cattle manure and chemical fertilizer on ammonia and particulate ammonium exchanges at an upland field. Atmos. Environ. 2009, 43, 5702-5707. [CrossRef]

18. Hwang, W.; Park, M.; Cho, K.; Kim, J.G.; Hyun, S.H. Mitigation of $\mathrm{CO}_{2}$ and $\mathrm{N}_{2} \mathrm{O}$ emission from cabbage field in Korea by optimizing tillage depth and N-fertilizer level: DNDC model simulation under RCP 8.5 scenario. Sustainability 2019, 11, 6158. [CrossRef]

19. NIAST. Method of Soil and Plant Analysis; National Institute of Agricultural Science and Technology, Rural Development Administration: Suwon, Korea, 2000.

20. Currie, L. Nomenclature in evaluation of analytical methods including detection and quantification capabilities: (IUPAC Recommendations 1995). Anal. Chim. Acta. 1999, 391, 105-126. [CrossRef]

21. Kim, M.S.; Lee, Y.S.; Min, H.G.; Kim, J.G. Applicability of the dynamic chamber-capture system (DCS) for estimating the flux of ammonia emission during liquid fertilizer spreading. Atmo. Pollut. Res. 2020, 11, 723-729. [CrossRef] 
22. Schjoerring, J.K.; Sommer, S.G.; Ferm, M. A simple passive sampler for measuring ammonia emission in the field. Water Air Soil Pollut. 1992, 62, 13-24. [CrossRef]

23. McGinn, S.M.; Sommer, S.G. Ammonia emissions from land-applied beef cattle manure. Can. J. Soil Sci. 2007, 87, 345-352. [CrossRef]

24. Yang, Y.; Zhou, C.; Li, N.; Han, K.; Meng, Y.; Tian, X.; Wang, L. Effects of conservation tillage practices on ammonia emissions from loess plateau rain-fed winter wheat field. Atmos. Environ. 2015, 104, 59-68. [CrossRef]

25. Hayashi, K.; Koga, N.; Fueki, N. Limited ammonia volatilization loss from upland fields of andosols following fertilizer application. Agric. Ecosys. Environ. 2011, 140, 534-538. [CrossRef]

26. Craswell, E.T.; Vlek, P.L.G. Fate of fertilizer nitrogen applied to wetland rice. In Gaseous Loss of Nitrogen from Plant-Soil System; Freney, J.R., Simpson, J.R., Eds.; Springer: Dordrecht, The Netherlands, 1983; Volume 9, pp. 237-264.

27. Su, C.; Yin, B.; Zhu, Z.; Shen, Q. Ammonia volatilization loss of nitrogen fertilizer from rice field and wet deposition of atmospheric nitrogen in rice growing season. J. Appl. Ecol. 2003, 14, 1884-1888.

28. Randy, J.D.; Nathan, A.S.; Richard, J.N.; Trenton, L.R. Ammonia volatilization, rice yield, and nitrogen uptake responses to simulated rainfall and urease inhibitor. Agron. J. 2017, 109, 363-377.

29. Hayashi, K.; Nishimura, S.; Yagi, K. Ammonia volatilization from the surface a Japanese paddy field during rice cultivation. Soil Sci. Plant Nut. 2006, 52, 545-555. [CrossRef]

30. Dewes, T. Ammonia emission during the initial phase of microbial degradation of solid and liquid cattle manure. Bioresour. Technol. 1999, 70, 245-248. [CrossRef]

31. Siman, F.C.; Andrade, F.V.; Passos, R.R. Nitrogen fertilizers and $\mathrm{NH}_{3}$ volatilization: Effect of temperature and soil moisture. Comm. Soil Sci. Plant Anal. 2020, in press. [CrossRef]

32. Hayashi, K.; Nishimura, S.; Yagi, K. Ammonia volatilization from a paddy field following applications of urea: Rice plants are both an absorber and an emitter for atmospheric ammonia. Sci. Total Environ. 2008, 390, 485-494. [CrossRef]

33. Fenn, L.B.; Hossner, L.R. Ammonia volatilization from ammonium or ammonium-forming nitrogen fertilizers. In Advances in Soil Science; Stewart, B.A., Ed.; Springer: New York, NY, USA, 1985; Volume 1, pp. 123-169.

34. Gao, H.; Bai, J.; Deng, X.; Lu, Q.; Ye, X. Short-term effects of tidal flooding on soil nitrogen mineralization in Chinese tidal salt marsh. Phys. Chem. Erath. 2018, 103, 3-10. [CrossRef]

35. DeLaune, P.B.; Moore, P.A.; Daniel, T.C., Jr.; Lemunyon, J.L. Effect of chemical and microbial amendments on ammonia volatilization composting poultry litter. J. Environ. Qual. 2004, 33, 728-734. [CrossRef]

36. Chastain, J.P. Ammonia volatilization losses during irrigation of liquid animal manure. Sustainability 2019 , 11, 6168. [CrossRef]

37. Sommer, S.G.; Génermont, S.; Cellier, P.; Hutchings, N.J.; Olesen, J.E.; Morvan, T. Processes controlling ammonia emission from livestock slurry in the field. Eur. J. Agron. 2003, 19, 465-486. [CrossRef]

38. Bouwmeester, R.J.B.; Vlek, P.L.G.; Stumpe, J.M. Effect of environmental factors on ammonia volatilization from a urea-fertilizer soil. Soil Sci. Soc. Am. J. 1985, 49, 376-381. [CrossRef]

39. Sommer, S.G.; Schjoerring, J.K.; Denmead, O.T. Ammonia emission from mineral fertilizers and fertilized crops. Adv. Agron. 2004, 82, 558-622.

40. Cameron, K.C.; Di, H.J.; Moir, J.L. Nitrogen losses from the soil/plant system: A review. Ann. Appl. Biol. 2013, 162, 145-173. [CrossRef]

(C) 2020 by the authors. Licensee MDPI, Basel, Switzerland. This article is an open access article distributed under the terms and conditions of the Creative Commons Attribution (CC BY) license (http://creativecommons.org/licenses/by/4.0/). 